\title{
ANALISIS PERSENTASE PENAMBAHAN PUPUK KANDANG (Kotoran Sapi) DAN LIMBAH TAHU DALAM PEMBUATAN BIOGAS
}

\author{
Muhammad Fitrah $^{1^{*}}$, Budy Wiryono ${ }^{2}$, Guyup Mahardian DP ${ }^{3}$, Asmawati $^{4}$ \\ ${ }^{1}$ Teknik Pertanian, Universitas Muhammadiyah Mataram, fitrahm532@gmail.com \\ ${ }^{4,2}$ Teknik Pertanian, Universitas Muhammadiyah Mataram \\ ${ }^{3}$ Teknik Pertanian, Universitas Mataram.
}

\section{INFO ARTIKEL}

Riwayat Artikel:

Diterima: 25-02-2018

Disetujui: 20-02-2018

\section{Kata Kunci: \\ Pupuk kandang \\ Kotoran Sapi \\ Limbah tahu \\ Biogas}

\begin{abstract}
ABSTRAK
Abstrak: Penelitian ini bertujuan untuk mengetahui presentase penambahan Kotoran Sapi (kotoran sapi) dan limbah tahu yang tepat dalam pembuatan biogas. Metode yang digunakan dalam penelitian ini adalah metode eksperimental dengan percobaan laboratorium. data hasil penelitian diolah dengan analisis keragaman (analisys of variance) pada taraf $5 \%$ dan jika ada perlakuan yang berpengaruh secara nyata, dilanjutkan dengan uji BNT pada taraf $5 \%$. Perlakuan yang terbaik diperoleh pada perlakuan K1 dengan persentase campuran (Air 1,5 L + Limbah Tahu 1,5 kg + Kotoran Sapi $1 \mathrm{~kg}$ ), yaitu, jumlah waktu pembentukan gas pada hari ke 3 , jumlah gas yang dihasilkan $52,15 \mathrm{~mm}^{3}$, nilai pH 6,28, nilai suhu $30.97^{\circ} \mathrm{C}$ dan nilai tekanan $100,32 \mathrm{~Pa}$.

Abstract:: This study aims to to know the percentage the addition of cow dung ( dirt cattle ) and waste know proper in the manufacture of biogas. The data the results of the study that it is processed from the analysis the diversity of (analisys of variance ) the first $5 \%$ and if there is a of being treated with influence significantly, when top flight sides enter by test bnt the first $5 \%$. Of being treated with best obtained the fire victims in $\mathrm{k} 1$ treatment being handed out with the percentage of a mixture of ( water 1,5l + any type of waste you know $1,5 \mathrm{~kg}+$ you have cow manure $1 \mathrm{~kg}$ ), pt pgn promised to supply, the amount of time the formation of gas on the th day of 3 , the amount of a gas that is produced $52,15 \mathrm{~mm} 3, \mathrm{ph}$ values 6,28 , the value of the temperature of 30.97 oc network and value of pressure 100,32 pa.
\end{abstract}

\section{A. LATAR BELAKANG}

Energi adalah salah satu sumber kehidupan yang sangat mendukung dalam kehidupan manusia yang memiliki peran yang sangat penting dalam aktifitas kehidupan manusia. Selama ini energi yang di perlukan masih dicukupkan dari sumber energi utama (bahan bakar fosil) yaitu, miyak bumi, batu bara dan gas(Supranto, 2005).

Penurunan kualitas energi dapat dilihat dari beberapa aspek dan salah satunya yaitu kebutuhan energi yang selalu mendominasi dalam kehidupan manusia sehingga memicu permasalahan ketergantungan terhadap energi membuat kebutuhan tidak seimbang dengan sumber energi yang dihasilkan sehinga lambat laut kualitas energi yang dibutuhkan tidak bagus.

Di Indonesia, sumber energi utama yaitu bahan bakar fosil seperti minyak bumi dan batu bara. Di satu sisi bahan bakar tersebut sangat memiliki dampak yang negatif dalam kehidupan manusia seperti dapat merusak lingkungan termasuk pencemaran udara, emisi gas rumah kaca dan pemanasan global(Hambali, 2007 dalam Febriyanita, 2015). Sedangkan bahan bakar yang berasal dari minyak bumi, gas maupun batu bara adalah sumber energi fosil yang tidak dapat diperbarui (Febriyanita, 2015)

Kebutuhan manusia terhadap energi yang terus bertambah membuat pasokan energi seperti bahan bakar fosil lambat laut akan habis. Konsumsi energi final di Indonesia meningkat dari 778 juta SBM pada tahun 2000 menjadi 1.211 juta SBM pada tahun 2013 atau tumbuh rata-rata sebesar 3,46\% per tahun(BPPT, 2015). Untuk mencegah terjadinya krisis energi salah satu alternatif yang harus dilewatin yaitu memikirkan untuk memunculkan sumber energi alternatif.

Energi alternatif/terbaharukan merupakan sumber energi ramah lingkungan yang tidak mencemari lingkungan dan tidak memberikan kontribu terhadap perubahan iklim dan pemanasan global seperti energi pengelolahan limbah untuk pembuatan biogas.

Biogas adalah gas yang dihasilkan oleh aktivitas anaerobik atau fermentasi dari bahan-bahan organik termasuk diantaranya : kotoran manusia, hewan, limbah domestik (rumah tangga)dalam kondisi anaerobik dengan adanya mikroorganisme penghasil metan yaitu Methanogen. Kandungan utama dalam biogas adalah metana dan karbon dioksida.Energi biogas yaitu energi yang dapat menganti bahan bakar gas LPG yang memiliki sifat non organik yang tidak dapat diperbaharukan (Priyadi, 2015).

Bahan - bahan yang digunakan dalam pembuatan biogas yaitu bahan - bahan organik seperti limbah pertanian, limbah peternakan, sampah rumah tangga, dan bahkan bisa 
mengunakan limbah kotoran manusia.Bahan yang sering digunakan dalam pembuatan biogas yaitu dengan mengunakan limbah peternakan dan pertanian seperti Kotoran Sapidan dan ampas tahu.

Kotoran Sapi (kotoran sapi) merupakan bahan yang dihasilkan oleh limbah peternakan yang sifatnya sangat banyak sehinga sedikit dalam pemanfaatanya.Selai dari pemanfaatan untuk pupuk organik, limbah perternakan seperti Kotoran Sapi (kotoran sapi) dapat digunakan dalam pembuatan biogas.

Selain dari limbah peternakan, limbah dari hasil pertanianpun sangat efektif dalam pembuatan biogas seperti limbah dari perusahaan pengolahan tahu (ampas tahu).Pada tahun 2014 tercatat jumlah industry makanan dan minuman mencapai 42 perusahaan pengelolahan hasil pertanian yang terdiri dari 123 perusahaan pengelolahan. Ini menunjukan bahwa jumlah populasi industri di NTB sangat besar, jika tidak ditangani dengan baik dalam pengelolahan limbah, maka akan memicu dampak negatif yang berdampak pencemaran lingkungan (BPS, 2016).

Berkaitan dengan limbah yang dihasilkan.Limbah tahu selain di manfaatkan untuk pakan ternak, limbah tahu memiliki sifat yang cepat terurai dan dapat pula diolah menjadi biogas, karena mengandung 50-80 \% metana, karbon dioksida, H2S, dan sedikit air yang bisa dijadikan sebagai pengganti minyak tanah dan LPG.

Berbekal dengan latar belakang permasalahan diatas maka, perlu dilakukan penelitian tentang komposisi yang tepat untuk pembuatan biogas dari Kotoran Sapi (kotoran sapi) dan limbah tahu.

\section{B. METODE PENELITIAN}

\section{Metode Penelitian}

Metode yang digunakan dalam penelitian ini adalah metode eksperimental dengan percobaan dilaboratorium.

\section{Rancangan Percobaan}

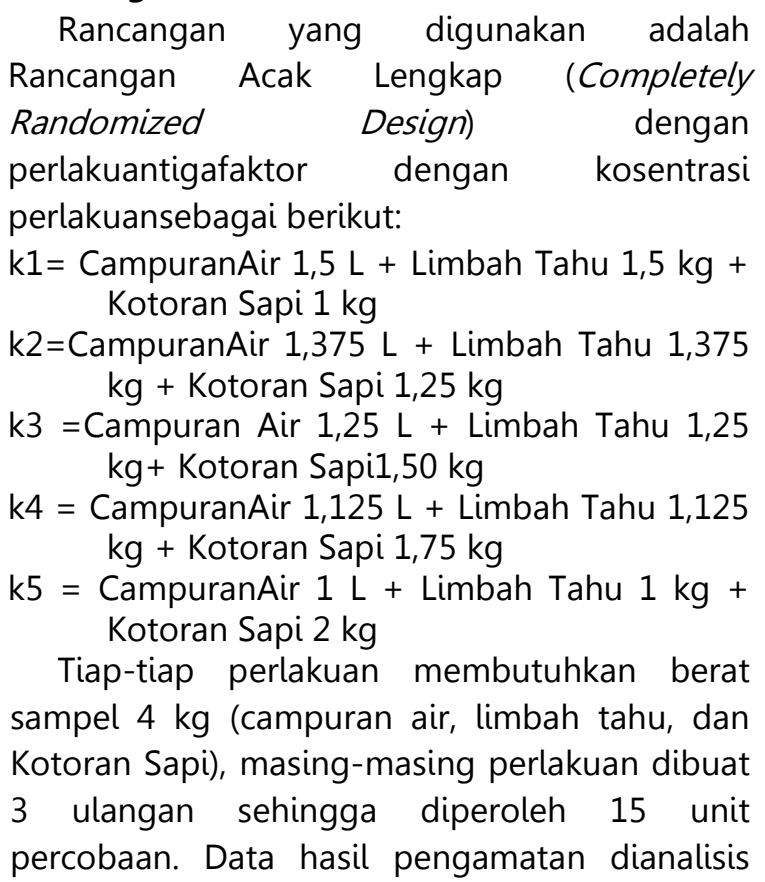

dengan Analisis Keragaman (Analisis of Variance) pada taraf nyata $5 \%$. Apa bila terdapat pengaruh beda nyata (signifikan), maka diuji lanjut dengan mengunakan uji Beda Nyata Terkecil (BNT) juga pada taraf nyata 5\% (Hanafiah, 2016).

\section{Waktu dan Tempat Penelitian}

Penelitian ini dilaksanakan dalam tiga tahap yaitu:

a. Tahap pertama di mulai dengan penyediaan alat dan bahan yang dilaksanakan di kampus Universitas Muhammadiyah Mataram dan di kediaman Pagesangan Baru pada tanggal 20 - 21 Maret 2017.

b. Tahap kedua adalah proses pembuatan bak penampung (digester mini) yang dilakukan diPagesanggan Baru pada tanggal 22 23Maret 2017.

c. Tahap ketiga adalah melakukan proses pembuatan biogas pada tanggal 23Maret 2017.

d. Pengamatan parameter penelitian dalam satu kali sehari pada tanggal 24 - 31 Maret 2017.

\section{Bahan dan Alat Penelitian}

a. Bahan

Adapun bahan yang di gunakan pada penelitian ini adalahAir, Kotoran Sapi dalam keadaan basah, dan Limbah tahu (Ampas +limbah air).

b. Alat penelitian

Adapun alat yang di gunakan pada penelitian ini adalah jerigen, gergaji, pipa ukuran $3 / 4$ inci, pipa siku $L$, lem pipa, lem $G$, salang kecil, penutup pipa, keran ukuran kecil, gunting pemotong, balon penampung, dan corong.

\section{Pelaksanaan Penelitian}

Dalam pelaksanaan penelitian melewati cara kerja yang sebagai berikut:

a. Persiapan alat dan bahan

Persiapan alat dan bahan adalah proses pengumpulan apa saja yang diperlukan untuk pembuata bak penampung dalam pembuatan biogas.

b. Pembuatan bak penampung

Pembuatan bak penpung dengan mengunakan bahan bekas seperti jerigen yang memiliki ukuran 5 Liter diawali denggan proses pembersihan pada jerigen, setelah dibersihkan, dilakukan proses pembolongan untuk memasangan bagianbagian pendukung seperti selang penghubung untuk menghitung nilai tekanan, jumlah gas yang dihasilkan, nilai $\mathrm{pH}$, dan nilai suhu. setelah di bikin lubang, maka dilakukan proses pemasangan dan 
pengeleman pada bagian-bagian yang telah dibikin terlebih dahulu seperti selang yang dihubungkan dengan balon penampung, selang pengeluaran, selang pengukur tekanan atau alat pipa $U$ dan pipa pengeluaran campuran biogas untuk mengukur nilai $\mathrm{pH}$ dengan tujuan untuk mengeratkan atau memperkuat rangkayan bak penampung sehingga tidak terjadi kebocoran. Adapun rangakaiyan bak penampung dapat ditunjukan pada gambar dibawah ini:

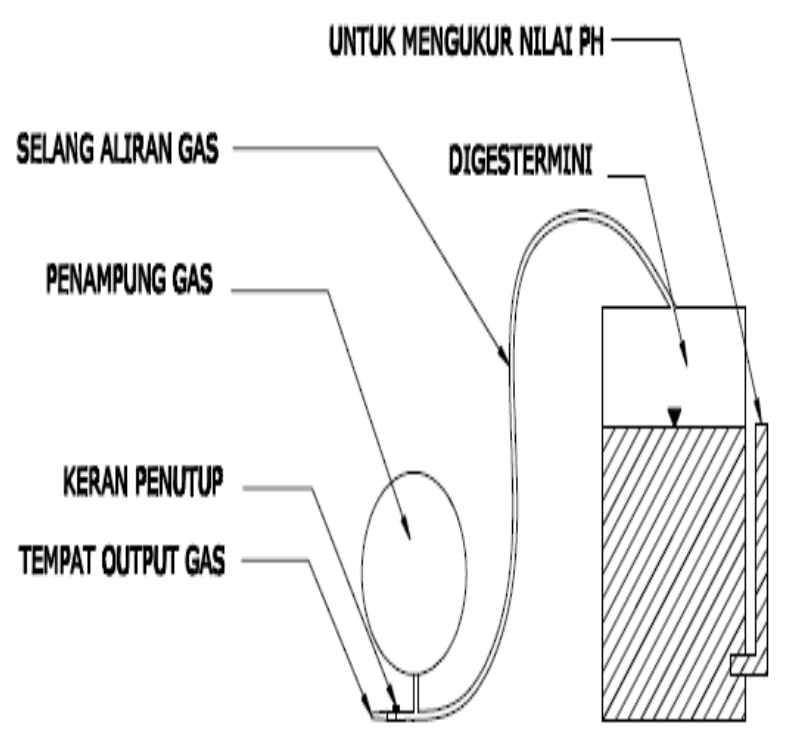

Gambar 3. Bentuk dan rangkaian Bak Penampung (Reaktor biogas)

Modifikasi dari Febriyanita, (2015).

Keterangan: Kapasitas bak penampung (Reaktor biogas) yaitu senilai 5 $\mathrm{kg}$ dengan panjang $=17 \mathrm{~cm}$, lebar $=11 \mathrm{~cm}$, dan tinggi $=26,5$ $\mathrm{cm}$

c. Pembuatan boigas

Bahan pembuatan biogas seperti air, limbah tahu, dan kotoran sapi ditimbang dan diukur dengan persentase yang ditetapkan. Bahan yang telah ditimbang lalu dicampurkan sehingga menjadi campuran biogas yang rata atau homogen.

d. Pemasukan dan penyimpanan

Langkah ini dilakukan setelah bahan di campurkan, proses pemasukan harus menurut pada perlakuan masing-masing. Setelah dimasukan dalam bak penampung, hal yang perlu diperhatikan adalah penyimpanan. Proses penyimpanan harus ditempat yang aman dan dapat dijangkau sehingga dapat mudah dalam melakukan proses analisis

e. Analisis perlakuan

Langkah ini adalah langkah proses dalam mengamati hasil percobaan yang berupa mengikuti parameter yang diamati seperti mengamati waktu pembentukan gas, jumlah gas yang dihasilkan, nilai $\mathrm{pH}$, nilai suhu, dan nilai tekanan yang dihasilkan oleh biogas. Adapun bagan alir dalam penelitian untuk analisis persentase penambahan Kotoran Sapi (kotoran sapi) dan limbah tahu dalam pembuatan biogas adalah, sebagai berikut:

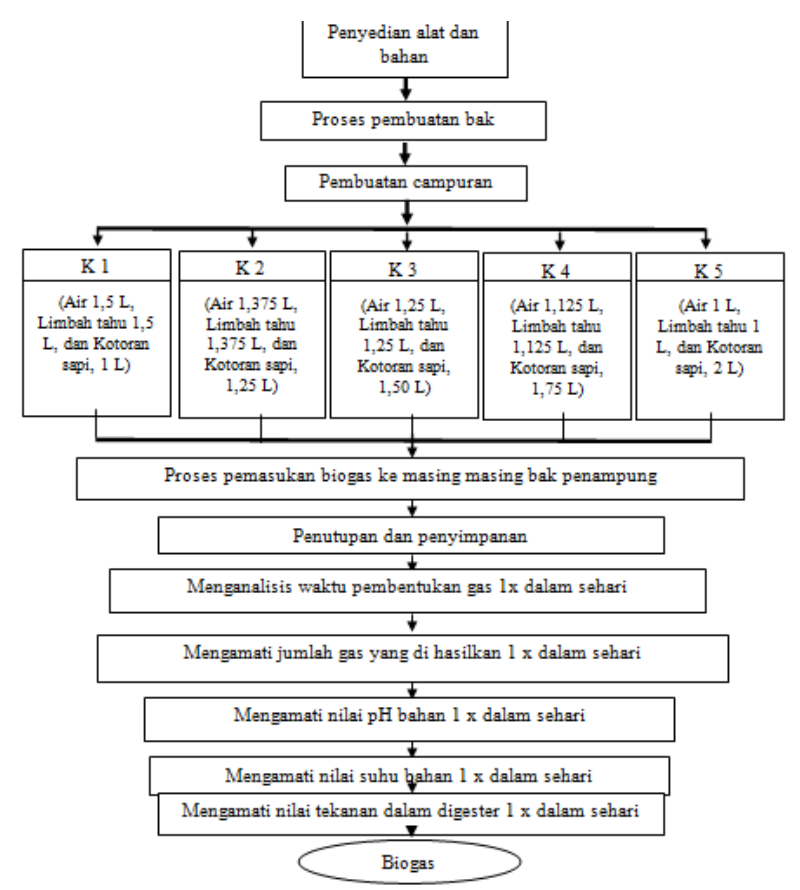

Gambar 4. Diagram alir proses pembuatan biogas dari kotoran sapi dan limbahtahu, modifikasih (Febriyanita, (2015))_

\section{Parameter dan Cara Pengukuran}

a. Parameter pengamatan

Parameter pengamatan yang diamati adalah waktu pembentukan gas, jumlah gas yang dihasilkan, nilai $\mathrm{pH}$, nilai suhu, dan nilai tekanan.

b. Pengukuran parameter

1) Waktu pembentukan gas

Cara pengukuran yang di gunakan yaitu, dalam mengukur waktu pembentukan gas, dengan cara membandingkan proses fisik terhadap penampung gas dari plastik penampung dengan sistem pengambilan data setiap 1 x dalam sehari pada jam 09.00 pagi yang diduga akan memiliki perbedaan dalam waktu pembentukan gas antar perlakuan sehingga memiliki waktu pembentukan gas yang dihasilkan berbeda (Ghevanda,2013).

2) Jumlah gas yang di hasilkan

Dalam mengukur jumlah gas yang di hasilkan yaitu dengan cara menghitung volume gas yang tertampung dalam plastik penampung yang berbentuk bulat, cara perhitungan volume gas yang dihasilkan 
dapat menggunakan rumus volume balon $=\frac{4}{3} \pi r^{2}$ dengan sistem pengambilan data 1 $x$ dalam sehari pada jam 09.15 pagi, sehingga mendapatkan jumlah gas yang dihasilkan dan membandingkan setiap perlakuan dengan perbedaan jumlah gas yang dihasilkan (ttps: // id. Wiki books .org /wiki/RumusRumus_Fisika_Lengkap/Gaya_d an_tekanan).

3) Nilai pH

Dalam mengukur nilai $\mathrm{pH}$, alat yang digunakan yaitu $\mathrm{pH}$ meter digital dengan sistem pengambilan data setiap $1 \times$ dalam sehari pada jam 09. 30, sehingga mendapatkan nilai $\mathrm{pH}$ larutan biogas (Saputra, 2016).

4) Nilai suhu $\left({ }^{\circ} \mathrm{C}\right)$

Untuk menghitung nilai suhu dapat menggunakan alat seperti thermometer yang di letakan pada digester dengan tujuan untuk mengetahui jumlah nilai suhu yang di hasilkan, dengan sistem pengambilan data setiap $1 \times$ dalam sehari pada jam 09.45 pagi (Sanjaya, 2015).

5) Nilai tekanan

Menurut "Sadzali, (2010), ada beberapa cara mengukur nilai tekanan, salah satunya yaitu dengan menggunakan alat manometer tipe pipa $U^{\prime \prime}$ dengan sistem pengambilan data setiap $1 \times$ dalam sehari pada jam 10.00 pagi.

\section{HASIL DAN PEMBAHASAN}

\section{Hasil Penelitian}

Hasil dan analisis hasil pengamatan disajikan dalam bentuk tabel di bawah ini, sedangkan hasil penelitian selengkapnya dapat dilihat pada lampiran 5. Signifikasi dari hasil pengamatan yang diperoleh dalam penelitian dapat dilihat pada Tabel 3 di bawah ini:

Tabel 3.Signifikasi persentase penambahan Kotoran Sapi (kotoran sapi) dan limbah tahu dalam pembuatan biogas terhadap lama waktu pembentukan gas, jumlah gas yang dihasilkan, nilai $\mathrm{pH}$, nilai suhu, dan nilai tekanan biogas.

Keterangan:S = Signifikan (berpengaruh secara nyata)

\begin{tabular}{cccc}
\hline Parameter & F hitung & $\begin{array}{c}\text { F tabel } \\
5 \%\end{array}$ & Signifikasi \\
\hline $\begin{array}{c}\text { Waktu } \\
\text { pembentukan gas }\end{array}$ & 26,66 & 9,01 & $\mathrm{~S}$ \\
$\begin{array}{c}\text { Jumlah gas yang } \\
\text { dihasilkan }\end{array}$ & 51,27 & 9,01 & $\mathrm{~S}$ \\
Ph & 0,45 & 3,97 & $\mathrm{NS}$ \\
Suhu & 0,55 & 3,97 & $\mathrm{NS}$ \\
Tekanan & 15,12683 & 9,01 & $\mathrm{~S}$ \\
\hline NS & $=$ Non Signifikan & (tidak & berpengaruh \\
& secara nyata) &
\end{tabular}

Pada Tabel 3 di atas menunjukan bahwa persentase penambaha Kotoran Sapi dan limbah tahu dalam pembuatan biogas berpengaruh secara nyata terhdap parameter yang diamati yaitu: waktu pembentukan gas, jumlah gas yang dihasilkan, dan nilai tekanan, perlu dilakukan uji lanjut dengan BNT pada taraf 5\% (table 4). Sedangka untuk parameter mengukur nilai $\mathrm{pH}$ dan suhu tidak berpengaruh secara nyata (no signifikan).

Purata hasil analisis dan uji lanjut jumlah persentase penambahan Kotoran Sapidan limbah tahu dalam pembuatan biogas terhadap lama waktu pembentukan gas, jumlah gas yang dihasilkan, nilai $\mathrm{pH}$, nilai suhu, dan nilai tekanan dapat dilihat pada Tabel 4 di bawah ini:

Tabel 4. Purata hasil analisispersentase penambahan Kotoran Sapi dan limbah tahu terhadap lama waktu pembentukan gas, jumlah gas yang dihasilkan, nilai $\mathrm{pH}$, suhu, dan nilai tekanan dari biogas.

\begin{tabular}{|c|c|c|c|c|c|}
\hline \multirow[b]{3}{*}{$\begin{array}{l}\text { Perla } \\
\text { kuan }\end{array}$} & \multicolumn{5}{|c|}{ Parameter } \\
\hline & 1 & & 3 & 4 & 5 \\
\hline & $\begin{array}{c}\text { Waktu } \\
\text { pembe } \\
\text { ntukan } \\
\text { gas } \\
\text { (hari) }\end{array}$ & $\begin{array}{c}\text { Jumlah } \\
\text { gas } \\
\text { yang } \\
\text { dihasil } \\
\text { kan } \\
\left(\mathrm{mm}^{3}\right)\end{array}$ & $\mathrm{pH}$ & $\begin{array}{l}\text { Suhu } \\
\left({ }^{\circ} \mathrm{C}\right)\end{array}$ & $\begin{array}{l}\text { Nilai } \\
\text { Teka } \\
\text { nan } \\
(\mathrm{Pa})\end{array}$ \\
\hline K1 & $3 c$ & $52,15 \mathrm{c}$ & 6,28 & 30,97 & $\begin{array}{c}100,3 \\
2 a\end{array}$ \\
\hline K2 & $3 c$ & $46,09 \mathrm{c}$ & 6,36 & 32,18 & $\begin{array}{c}100,3 \\
2 a\end{array}$ \\
\hline K3 & $4,33 \mathrm{~b}$ & $\begin{array}{c}23,99 \\
b\end{array}$ & 6,51 & 31,82 & $\begin{array}{c}100,2 \\
2 b\end{array}$ \\
\hline K4 & 5,66 a & $11,24 a$ & 6,77 & 31,24 & $\begin{array}{c}100,1 \\
4 c\end{array}$ \\
\hline K5 & 5,66 a & $16,10 \mathrm{a}$ & 6,71 & 31 & $\begin{array}{c}100,1 \\
3 \mathrm{c}\end{array}$ \\
\hline $\begin{array}{l}\text { Nilai } \\
\text { BNT }\end{array}$ & 0,813 & 8,024 & - & - & 0,076 \\
\hline & & $\begin{array}{l}\text { a-angk } \\
\text { ha pada } \\
\text { beda } \\
\text { la taraf }\end{array}$ & $m$ & $\begin{array}{l}\text { uti h } \\
\text { gg sa } \\
\text { ar }\end{array}$ & $\begin{array}{l}\text { f yang } \\
\text {, tidak } \\
\text { lakuan }\end{array}$ \\
\hline
\end{tabular}

Pada Tabel 4 kolom 1 (waktu pembentukan gas) menunjukan bahwa perlakua K1 tidak berbeda nyata dengan $K 2$, tetapi berbeda nyata dengan K3,K4, dan K5. Perlakuan K2 tidak berbeda nyata dengan $K 1$, tetapi berbeda nyata dengan K3, K4, dan K5. Perlakuan K3 berbeda nyata dengan $K 1, K 2, K 4$, dan K5. Perlakuan K4 tidak berbeda nyata dengan $K 5$, tetapi berbeda nyata dengan K1, K2 dan K3. Perlakuan K5 tidak berbeda nyata dengan $\mathrm{K} 4$, tetapi berbeda nyata dengan $\mathrm{K} 1, \mathrm{~K} 2$, dan $\mathrm{K} 3$.

Pada Tabel 4 kolom 2 (jumlah gas yang dihasilkan) menunjukan bahwa pada perlakua 
K1 tidak berbeda nyata dengan $\mathrm{K} 2$, tetapi berbeda nyata dengan K3,K4, dan $\mathrm{K} 5$. Perlakuan $\mathrm{K} 2$ tidak berbeda nyata dengan $\mathrm{K} 1$, tetapi berbeda nyata dengan K3, K4, dan K5. Perlakuan K3 berbeda nyata dengan K1, K2, K4, dan K5. Perlakuan K4 tidak berbeda nyata dengan $\mathrm{K} 5$, tetapi berbeda nyata dengan $\mathrm{K} 1, \mathrm{~K} 2$ dan K3. Perlakuan K5 tidak berbeda nyata dengan $K 4$, tetapi berbeda nyata dengan $K 1, K 2$, dan K3.

Untuk parameter $\mathrm{pH}$ dan suhu, tidak berbeda nyata antar perlakuan.Hal ini disebabkan karena $F$ hitung lebih kecil dari $F$ tabel.Sehinga tidak dilakukan uji lanjut dengan BNT.

Pada Tabel 4 kolom 5 (nilai tekanan) menunjukan bahwa pada perlakua K1 tidak berbeda nyata dengan $\mathrm{K} 2$, tetapi berbeda nyata dengan K3,K4, dan K5. Perlakuan K2 tidak berbeda nyata dengan $K 1$, tetapi berbeda nyata dengan K3, K4, dan K5. Perlakuan K3 berbeda nyata dengan $\mathrm{K} 1, \mathrm{~K} 2, \mathrm{~K} 4$, dan $\mathrm{K} 5$. Perlakuan $\mathrm{K} 4$ tidak berbeda nyata dengan $K 5$, tetapi berbeda nyata dengan K1, K2 dan K3. Perlakuan K5 tidak berbeda nyata dengan $K 4$, tetapi berbeda nyata dengan $\mathrm{K} 1, \mathrm{~K} 2$, dan $\mathrm{K} 3$.

\section{Pembahasan}

a. Waktu pembentukan gas

Pada Tabel 4 kolom 1 menunjukan bahwa waktu pembentukan gas paling cepat terjadi pada perlakuan K1 (CampuranAir 1,5 L + Limbah Tahu 1,5 kg + Kotoran Sapi $1 \mathrm{~kg}$ ) selama 3 hari dan tidak berbeda nyata dengan perlakuan K2 (campuran air 1,375 L + Limbah Tahu 1,375 kg + Kotoran Sapi 1,25 kg), dan yang paling lambat pembentukan gas adalah pada perlakuan K4 (campuran Air 1,125 L + Limbah Tahu 1,125 kg + Kotoran Sapi 1,75 kg) dan K5 (campuran Air $1 \mathrm{~L}+$ Limbah Tahu 1 kg + Kotoran Sapi 2 kg) selama 5,6 hari.

Adapun grafik pengaruh persentase penambahan pupuk kandang dan limbah tahu dalam pembuatan biogas terhadap lama waktu pembentukan gas dapat dilihat pada gambar dibawah ini:

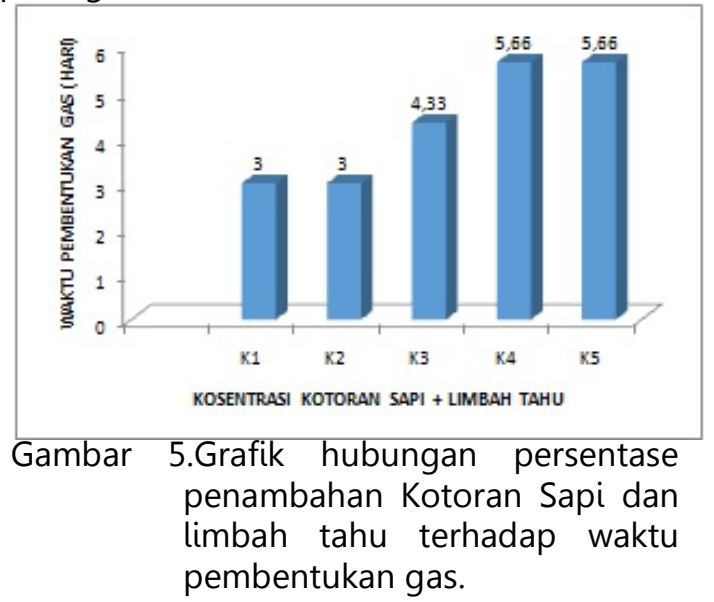

Semakin tinggi campuran kotoran sapi dan semaki rendah limbah tahu dan air yang digunakan maka lama waktu pembentukan gas semakin lama.Hal ini disesabkan karena campuran biogas yang padat.

Pada campuran biogas yang mengandung limbah tahu terbanyak memiliki tingkat produksi biogas yang sangat tinggi. Ini diperkuat oleh teori yang menjelaskan bahwa dalam kandungan limbah tahu memiliki $0,63 \%$ volatile solid, dimana volatile solid yang tinggi meningkatkan produksi biogas (Widarti, 2012 dalam Saputra, 2016)

b. Jumlah gas yang dihasilkan

Pada Tabel 4 kolom 2menunjukan bahwa jumlah gas yang dihasilkan paling banyak pada perlakuan K1 (CampuranAir 1,5 $\mathrm{L}+$ Limbah Tahu 1,5 kg + Kotoran Sapi 1 kg) sebesar $52,15 \mathrm{~mm}^{3}$ dan tidak berbeda nyata dengan perlakuan K2 (campuran air 1,375 L + Limbah Tahu 1,375 kg + Kotoran Sapi 1,25 $\mathrm{kg}$ ) sebesar $46,09 \mathrm{~mm}^{3}$, dan yang paling sedikit jumlah gas yang dihasilkan adalah pada perlakuan K4 (campuran Air 1,125 L + Limbah Tahu 1,125 kg + Kotoran Sapi 1,75 $\mathrm{kg}$ ) sebesar $11,24 \mathrm{~mm}^{3}$.

Adapun grafik pengaruh persentase penambahan pupuk kandang dan limbah tahu dalam pembuatan biogas terhadap jumlah gas yang dihasilkan dapat dilihat pada gambar dibawah ini:

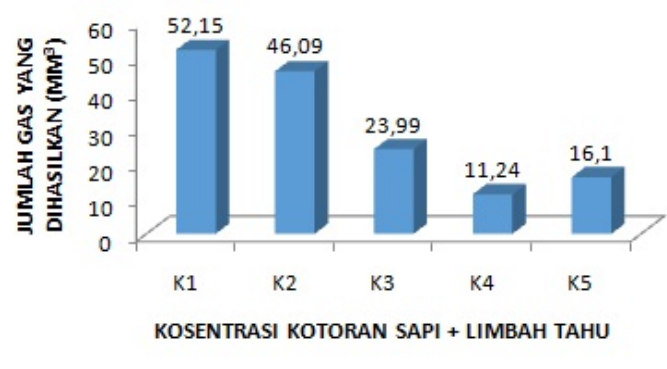

Gambar 6.Grafik hubungan persentase penambahan Kotoran Sapi dan limbah tahu terhadap jumlah gas yang dihasilkan.

jika pada campuran biogas memiliki sifat terlalu kental atau padat maka jumlah gas yang terproduksi semakin rendah. Hal ini disebabkan kosentrasi campuran yang terlalu kental dan jumlah campuran kotoran sapi yang terlalu tinggi dan air yang sedikit menyebabkan kepadatan pada campuran biogas, maka sangat susah dalam proses fermentasi. Syarat untuk pembentukan pembuatan biogas yaitu campuran bahanya tidak terlalu kental dan tidak terlalu cair (Ghevanda, 2013) 
c. Jumlah nilai $\mathrm{pH}$ campuran bahan biogas

Pada Tabel 4 kolom 3 menunjukan bahwa nilai $\mathrm{pH}$ antar perlakuan tidak memiliki perbedaan nilai antar perlakuan (non signifikan). Nilai $\mathrm{pH}$ antar perlakuan rata-rata standar kisaran 6,28 sampai 6,77. Ini membuktikan bahwa parameter mengukur nilai $\mathrm{pH}$ tidak berpengaruh terhadap persentase penambahan Kotoran Sapi dan limbah tahu dalam pembuatan biogas. Adapun data nilai $\mathrm{pH}$ dapat ditunjukan oleh gambar di bawah ini:

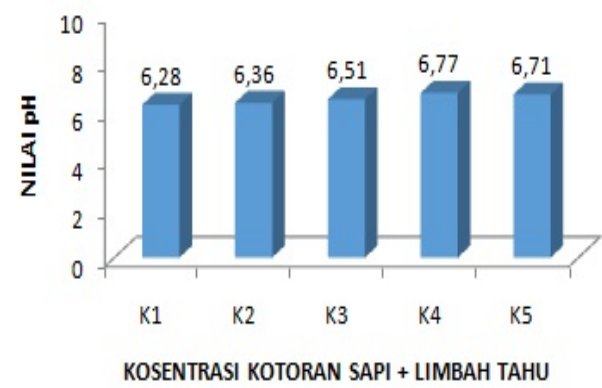

Gambar 7.Grafik hubungan persentase penambahan Kotoran Sapi dan limbah tahu terhadap nilai $\mathrm{pH}$ biogas.

Nilai pH bahan awal campuran biogas sebelum dicampurkan terdiri dari air: $6,90 \mathrm{pH}$, Kotoran sapi: 7,40 pH, dan limbah tahu: 5,85. Setelah di campurkan dan dianalisis dengan proses pengambilan data/hari nilai $\mathrm{pH}$ bahan menjadi rata-rata 6 .

Berlandaskan dengan teori yang berlaku, bahwa produksi biogas secara optimum dapat dicapai bila nilai $\mathrm{pH}$ dari campuran masuk di dalam digester berada pada kisaran 6 dan 7. Pada tahap awal proses fermentasi, asam organik dalam jumlah besar diproduksi oleh bakteri pembentuk asam, pH dalam digester dapat mencapai 5. Keadaan ini cenderung memperhentikan proses pencernaan atau fermentasi. Ketika produksi metan dalam kondisi stabil, maka nilai $\mathrm{pH}$ adalah kisaran 7,2 sampai 8,2 (Saputra, 2016)

d. Nilai suhu digester

Pada Tabel 4 kolom 4 menunjukan bahwa nilai suhu antar perlakuan tidak memiliki perbedaan nilai antar perlakuan (non signifikan). Nilai suhu antar perlakuan rata-rata standar kisaran $30,97^{\circ} \mathrm{C}$ sampai $32,18^{\circ} \mathrm{C}$. Ini membuktikan bahwa parameter mengukur nilai suhu tidak berpengaruh secara nyata terhadap persentase penambahan Kotoran Sapi dan limbah tahu dalam pembuatan biogas. Adapun data nilai suhu dapat ditunjukan oleh gambar di bawah ini:

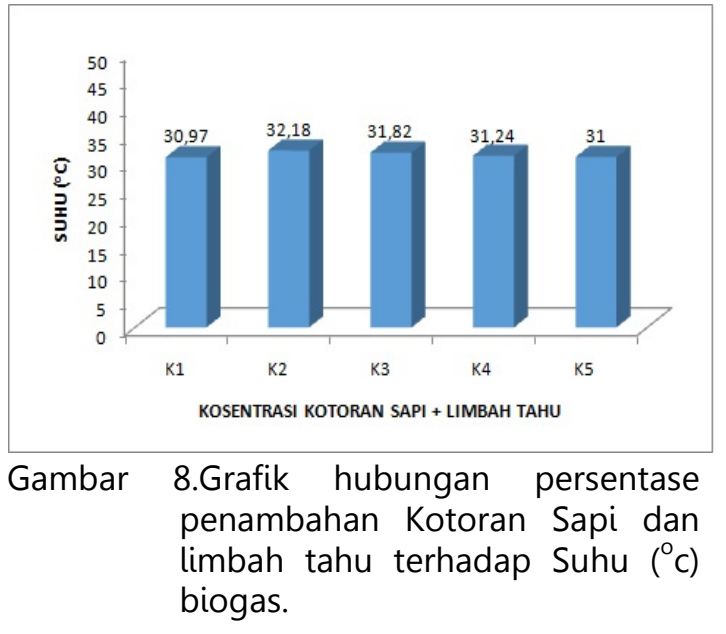

Nilai suhu digester tidak jauh berbeda dengan suhu ruangan.Suhu digester standar dari $30{ }^{\circ} \mathrm{C}$ sampai $34{ }^{\circ} \mathrm{C}$. nilai suhu jika dirataratakan maka mendapatkan nilai pada tiap perlakuan tidak memiliki perbedaaan yang terlalu jauh antar perlakuan.Hal ini di karenakan bahwa dalam analisis persentase penambahan Kotoran Sapi dan limbah tahu dalam pembuatan biogas tidak berpengaruh terhadap para meter suhu.

Untuk proses pembentukan gas dalam bak penampung memerlukan suhu yang bagus. Bakteri metonogen dalam keadaan tidak aktif pada kondisi suhu yang ekstrim tinggi maupun rendah. Suhu optimumnya yaitu $35{ }^{\circ} \mathrm{C}$. ketika suhu udara mencapai $10^{\circ} \mathrm{C}$ maka produksi gas menjadi berhenti" temperatur yang baik dalam proses pembentukan biogas berkisar antara $20-40$ ${ }^{\circ} \mathrm{C}$ (Sanjaya, 2015)

e. Nilai tekanan biogas dalam digester

Pada Tabel 4 kolom 5 menunjukan nilai tekanan gas yang dihasilkan paling tinggi pada perlakuan K1 (CampuranAir 1,5 L + Limbah Tahu 1,5 kg + Kotoran Sapi 1 kg) sebesar 100,32 Pa dan tidak berbeda nyata dengan perlakuan K2 (campuran air 1,375 L + Limbah Tahu 1,375 kg + Kotoran Sapi 1,25 kg) sebesar 100,32 Pa, dan yang paling sedikit jumlah gas yang dihasilkan adalah pada perlakuan K5 (campuran Air $1 \mathrm{~L}+$ Limbah Tahu $1 \mathrm{~kg}$ + Kotoran Sapi 2 kg) sebesar 100,13 Pa.

Adapun grafik pengaruh persentase penambahan pupuk kandang dan limbah tahu dalam pembuatan biogas terhadapnilai tekanan yang dihasilkan dapat dilihat pada gambar di bawah ini: 


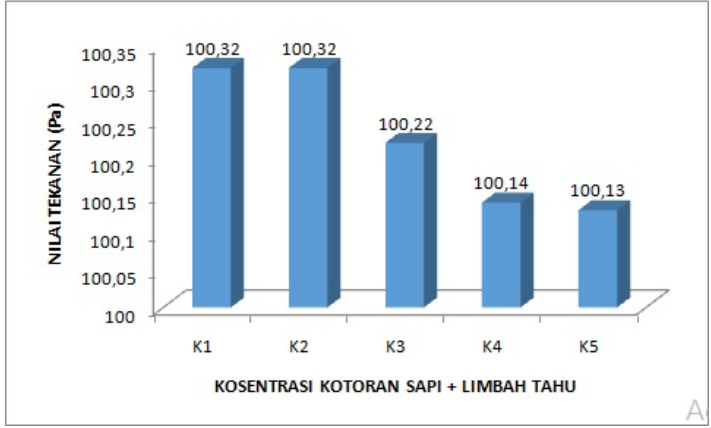

Gambar 9.Grafik hubungan persentase penambahan Kotoran Sapi dan limbah tahu terhadap nilai tekanan $(\mathrm{Pa})$

jika pada campuran biogas memiliki sifat terlalu kental atau padat maka jumlah gas yang terproduksi semakin rendah, lama waktu pembentukan gas akan semakin lama. Hal ini disebabkan kosentrasi campuran yang terlalu kental dan jumlah campuran kotoran sapi yang terlalu tinggi dan air yang sedikit menyebabkan kefakuman pada campuran biogas, maka berengaruh terhadap nilai tekanan yang dihasilkan. Nilai tekanan akan meningkat dikarenakan adanya gas yang terbentuk (Saputra, 2016)

\section{SIMPULAN DAN SARAN}

Berdasarkan hasil dan analisa hasil serta pembahasan yang terbatas pada ruang lingkup penelitian ini dapat ditarik kesimpulan sebagai berikut:

a. Persentase penambahan, kotoran sapi, limbah tahu dan air berpegaruh terhadap waktu pembentukan gas, jumlah gas yang dihasilkan, dan nilai tekanan, tetapi tidak berpengaruh terhadap nilai $\mathrm{pH}$ dan suhu.

b. Semakin tinggi persentase penambahan kotoran sapi dan semakin rendah ampas tahu dengan jumlah penambahan air yang semakin sedikit maka waktu yang dibutuhkan untuk pembentukan gas akan semakin lama, jumlah gas yang dihasilkan sedikit, dan nilai tekanan akan semakin rendah, sedangkan untuk parameter nilai suhu dan $\mathrm{pH}$ cenderung nilai semakin tinggi.

c. Hasi analisi menunjukan bahwa perlakuan yang terbaik terlihat pada K1 dengan persentase campuran Air 1,5 L + Limbah Tahu $1,5 \mathrm{~kg}+$ Kotoran Sapi $1 \mathrm{~kg}$ yaitu, jumlah waktu pembentukan gas pada hari ke 3 , jumlah gas yang dihasilkan $52,15 \mathrm{~mm}^{3}$, nilai $\mathrm{pH} 6,28$, nilai suhu $30.97{ }^{\circ} \mathrm{C}$ dan nilai tekanan $100,32 \mathrm{~Pa}$.

\section{UCAPAN TERIMA KASIH}

Penulis mengucapkan terima kasih kepada Bapak Budy Wiryono S.TP.,M.Si. dan Guyup Mahardian DP S.TP,.M.Si. yang senantiasa memberikan bimbingan, nasehat, dan motivasi kepada penulis sehingga penelitian ini selesai dengan baik.

\section{DAFTAR RUJUKAN}

\section{Buku}

[1] Supranto., 2005. Teknologi Tenaga Surya, Global Pustaka Utama: Yugyakarta.

[2] Hanafiah, K, A., 2016, Rancangan Percobaan, Fajar Interpratama Mandiri: Palembang.

\section{Jurnal}

[3] BPPT, 2015. Pengembangan energy untuk mendukung pembagunan berkelanjutan, Badan Pengkajian Dan Penerapan teknologi: Jakarta.

[4] BPS, 2016, PopulasiSapi, NTB: Badan Pusat Statistik (BPS)

[5] BPS, 2016, Produksi Industri Makanan dan Minuman Mikro Dan Makro, Badan Pusat Statistik (BPS): NTB.

[6] Febriyanita, W., 2015. Pengembangan biogas dalam rangka Pemanfaatan energy terbarukan di desa jetak Kecamatan Getasan Kabupaten Semarang, Universitas Negeri Semarang: Semarang

[7] Ghevanda, I.,Triwikantoro., 2013. Analisis Peran Limbah Sayuran dan Limbah Cair Tahu pada Produksi Biogas Berbasis Kotoran Sapi, Institut Teknologi Sepuluh: Surabaya.

[8] Priyadi, F.,Subiyanta, E., 2015, Studi Potensi Biogas dari Kotoran Ternak Sapi Sebagai Energi Alternatif, Universitas 17 Agustus 1945 (UNTAG 45): Cirebon.

[9] Sadzali, I., 2010, Potensi Limbah Tahu Sebagai Biogas, universitas Indonesia: Jawa Barat.

[10] Saputra, P., 2016, Potensi Campuran Limbah Cair Industri Tahu Dan Kotoran Sapi Sebagai Substrat Penghasil Biogas, Universitas Islam Negeri Maulana Malik Ibrahim Malang: Malang.

[11] Sanjaya, D.,Haryanto, A., Tamrin.,2015, Produksi Biogas Dari Campuran Kotoran Sapi Dengan Kotoran Ayam, Universitas Lampung: Lampung. 